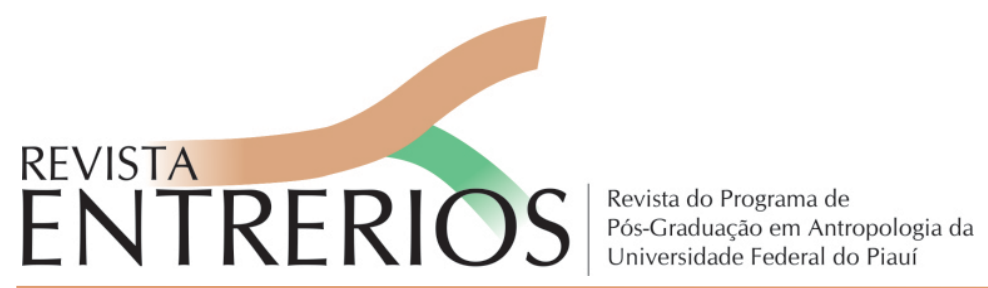

\title{
LA CADENA, Marisol de; BLASER, Mario. A world of many worlds. Durham e London: Duke University Press, 2018.
}

\author{
Potyguara Alencar dos Santos \\ Pesquisador PNPD/Capes do Programa de Pós-Graduação em Antropologia \\ da Universidade Federal do Piauí (PPGAnt/UFPI) \\ E-mail: potyguara.alencar@gmail.com.
}

A World of Many Worlds é uma aproximação de seis escritos da literatura antropológica contemporânea que ocorre sob às urgências reflexivas de dois eventos: os sinais estertorados pelo Antropoceno - essa guerra sub-repticiamente declarada da espécie contra si mesma, como afirmam Viveiros de Castro e Danowski no último texto da coletânea - e a perspectiva de uma indagação e abordagem sobre suas evidências. Mundos e pluriverso são as entradas que tentam elidir os projetos reunidos pelo livro, que também se conformam à proposição maior lançada pelos organizadores: pensar "mundos heterogêneos que caminham juntos como uma ecologia política das práticas, negociando suas dificuldades em conviverem a partir dessa mesma heterogeneidade" (DE LA CADENA; BLASSER, 2018, p. 4).

Longe de apresentar somente um outro elogio ao predicado da diversidade e do seu proveito pela antropologia, o que se inaugura na coletânea é um contraponto às leituras terminantes que antecipam suas "narrativas do fim" ante os esforços em pensar formas de convivência entre os mundos, suas ontologias e suas cosmopolíticas constitutivas.

Embora a experiência refletida da etnografia se manifeste ao longo dos artigos, como na contribuição de Hellen Verran sobre as interações epistêmicas entre a matemática e a etnomatemática nas escolas aborígenes do norte da Austrália, ou no texto de John Law e Marianne Lien, sobre o manejo conceitual e técnico da natureza envolvido nas práticas criatórias do salmão nas fazendas piscicultoras noruegueses, a tônica da coletânea não torna sobressalente o produto etnográfico sistematizado como dado principal. Como anseia o programa mais amplo do livro à maneira como é comunicado pelos organizadores na sua introdução -, a proposta é dar exploração a termos conceituais advindos da qualidade sensível (empírica e ôntica) e conceituante da etnografia e das suas "chaves entre mundos" que considerem as tentativas em toda parte produzidas, seja pela expressão de maneiras mais mecânicas ou mais espontâneas de aproximar e fazer conviver experiências alternas de mundos.

Por esse interesse sobre as condições diversas e, por vezes, antitéticas que possibilitam a convivência, as contribuições dos autores reincidem em termos que inspiram "liame", "amálgama", "negociação" e "acordo": assim ocorre com a contribuição de Marylin Strathern, 
em Opening Up Relations, e o seu investimento analítico na relacionalidade envolvida nos contatos entre domínios de conhecimento pela aproximação e pela divergência; também ganha forma na ideia de uma "diplomacia entre mundos" explorada por Isabelle Stengers, em The Challenge of Ontological Politics, quando investiga os limites de uma "ontologia política" que dê conta de reconhecer pluriversos pelas suas convivências e mútuas participações; pontua, da mesma forma, a imagística de valor heurístico da "teia de aranha" trazida por Alberto Corsín Jiménez, em Spiderweb Anthorpologies, quando trata das "armadilhas" (nas ecologias e na própria arte escriturária do etnógrafo) que, fatalmente, apreendem e apresam o próprio produtor na sua obra.

Há uma ambivalência adequada disposta ao longo de todos os escritos e, claro, no seu projeto maior: ao passo que questionam as fórmulas que tentam ordenar a realidade pelos primados da unicidade das experiências e do extrativismo como uma força que torna o mundo uma unidade em digestão produtiva padronizada, também investigam os modos alternativos e necessários de "aproximar as ontologias", de direcionar a própria etnografia às composições que manifestam os pluriversos. A ideia de conhecimento é, por exemplo, reportada por inúmeras vozes autorais, direta e indiretamente, como um domínio que só se realiza em suas "individualidades" manifestas na medida que negociam ideias entre si, na proporção que suas partes aceitam abrir espaços relacionais. De sua parte, a etnografia, em sua rotina prático-teórica essencial, seria a intervenção que reconhece os conceitos emergentes dos contatos entre mundos, esses termos que, segundo a afirmação de Isabelle Stengers (2018, p. 884), são como meios "para negociar as frágeis fronteiras do multiverso". Para essa autora, a ontologia política seria, antes de tudo, o lugar através do qual “os mundos falam”, expressam-se como multivocalidades, e assim o fazem para além de uma "situação de isonomia"; essa qualidade que está mais para a concepção estritamente política de realidade, do que para a manifestação ontológica dos mundos.

Como fecho argumentativo do livro - considerando a existência de uma interação escalar e coerente entre as diversas contribuições -, Eduardo Viveiros de Castro e Déborah Danowski vêm lembrar que os declives ambientais e sociais do Antropoceno potencializam as experiências antecipadas e reais do fim, acentuando cada vez mais as linhas de co-dependência que unificam (sem aplainar) as bases sobre as quais crescem as várias experiências de mundos. A perspectiva do pluriverso é indiretamente reavida nesse artigo pela própria evidência contingencial do efeito catastrófico, esse operado sob o efeito trágico em que os "invasores são (também) os invadidos, os colonizadores são (também) os colonizados" (VIVEIROS DE CASTRO; DANOWSKI, 2018, p. 194).

Mirada sua forma integral, e sabendo o histórico das colaborações que a geraram, a coletânea nos apresenta o produto de um esforço que poderia ser espelhar para outras publicações do mesmo gênero: ali, os textos são como resultados de contatos de perspectivas que foram se adensando entre encontros de companheiros de reflexão ao longo de tempos bem aproveitados, qualitativamente produtivos, o que acabou imprimindo na obra um conteúdo heterogêneo mas ainda dialogante entre as evoluções da suas folhas e argumentos. De um modo geral, A World of Many Worlds nos faz lembrar um gesto de ralento e apuração das ideias que o produtivismo acadêmico fatalmente engolfa no nosso dia a dia. Dessa forma, ele também cede recordação ao fato de que um livro, esse pluriverso transportável, essa teia-de-aranha que é feita para os outros, mas que antes tem que nos enredar - como pontua Alberto Corsín Jiménez -, deve ser sempre resultado de uma duração que desacelera os mundos da vida (inclusive os nossos, dos autores) para clarear suas intensidades. 